\title{
入 射 $\mathrm{X}$ 線 摇動法による応力測 定*
}

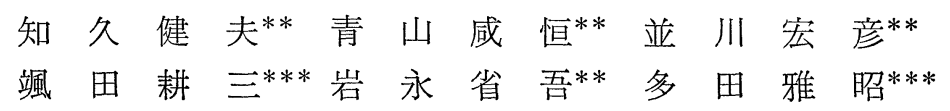

\author{
Stress Measurement by Oscillation Technique of X-Ray Optical System \\ by
}

\author{
Takewo CHIKU, Shigetsune AOyama, Hirohiko NamiKawa, \\ Kouzo SATTA, Syogo IwANAGA and Masaaki TADA \\ (Toyota Central Research and Development Labs., Inc., Nagoya)
}

In order to make X-ray measurement of stress using oscillation technique, its optimum conditions were studied with respect to the grain size of the specimen and the geometrical conditions of the soller slit system. Investigation was also made of the influence that the oscillating angle, the oscillating speed and the time constant would have on the diffraction profiles or the stress determined by X-rays.

The abnormality of diffraction profile of coarse grained specimen, caused by the geometrical conditions of the soller slit system, decreased by the oscillation of the X-ray optical system. And the number of grains, which contributed to the diffraction, increased by the oscillation technique. The diffraction profile obtained with the instrument became normal, when the range of oscillating angle was twice as large as the half breadth of the diffraction profile. And the peak position of diffraction profile could also be determined with ease.

The periodic change of intensity was observed on the diffraction profile when the oscillation technique was used. This phenomenon was remarkable with the increase of incident angle $\psi_{0}$. It was due to the difference of diffracted X-ray intensity for different angle in oscillation. When smaller oscillating angle than $\pm 15^{\circ}$ was chosen, however, the periodic change in intensity of the diffraction profile was kept sufficiently small under the time constant 8 or 16 sec. which was what is generally used.

The analytical results showed that the value of $\operatorname{cosec} \theta$ obtained from the oscillation technique was not exactly proportional to that of $\sin ^{2} \psi$. But the experimental results showed that the $\operatorname{cosec} \theta-\sin ^{2} \psi$ relations obtained in the oscillating condition became approximately linear. The stress value of $\mathrm{Fe}\{211\}$ determined by conventional $\sin ^{2} \psi$ method using the data of $\pm 10^{\circ}$ oscillating condition, appeared to be $4 \sim 6 \%$ smaller than that obtained from the data of fixed condition. $\operatorname{Sin}^{2} \psi$ method seems to be practically useful to determine the stress, even when the oscillation technique is adopted, supposing that the oscillating angle is not so large and the stress of the specimen is not so high.

(Received Aug. 12, 1970)

\section{1 緒言}

粗大結晶粒試料（結晶粒径：10 $\mu$ もしくはそれ以 上) のX線応力測定では, 微小結晶粒の試料から得ら 孔る回折強度曲線と比べると強度分布汇異常が認めら れることがある。このような場合, 試料を入射X線ビ 一ムに対して摇動させて, 回折にあずかる結晶数の増

* 原稿受理 昭和45年 8 月 12 日

** 正 会 員 (株) 豊田中央研究所 名古屋市昭和区久方

$* * *$

同上
加をはかると, 正常な回折強度曲線が得られた。しか し, 試料が大きいとき, あるいは試料が試験機等に取 り付けてある場合には，この手法を適用することにも 制限が多い。このような難点を解決するために, 試料 固定のま香で同様の効果を期待できる入射 $\mathrm{X}$ 線摇動法 を開発した。

本報告では, 入射 X線の摇動角度の決定基準を, 結 晶粒径と装置の幾何学的関係から検討し, さらに, 摇 動角度, 摇動速度, タイムコンスタント等の因子が, 
回折強度曲線あるいは応力值にどのような影響を与え るか調査した。

\section{2 摇動角度の検討}

\section{$2 \cdot 1$ 回折強度分布を考慮した場合}

入射 X線摇動を行なわない場合, 検出 $\mathrm{X}$ 線の強度は, 検出器の走査にしたがって，こくこく異なった結晶に よって与えられる. 平行ビーム型ディフラクトメータ の場合も, ソーラスリットの開き角度内に特いてX線 ビームの発散がある。しかも，入射 X線の方向と試料 との位置関係が固定されているために，個々の結晶は その回折強度分布の一部の強度しか検出器に与㒵ない. 回折されるX線の強度や方向は各結晶粒ごとに異なる から，回折にあずかる結晶数が少なくなると，特定な 角度にの夕回折強度が強調され, 回折強度曲線の形が 異常になる。乙かし, 回折強度曲線の形に異常が認め られた結晶粒径 $15 \mu, 30 \mu, 50 \mu$ の $\mathrm{Fe}$ 材の場合, $\pm 3^{\circ}$ の摇動を行ならと, 半価幅の值が読み取り誤差範 囲内で一定となり，回折ピーク位置のばらつきも小さ くなった。

そこで，入射X線摇動が回折強度曲線に及ぼす効果 をさらに詳しく調べるため，いくつかのX線照射面積 と摇動角度の組み合せのもとで, 回折ピーク位置のば らつきを測定した。

Table I は結晶粒径 $50 \mu$ の Fe 材について, X線 入射角度 $\psi_{0}=0^{\circ}$ V和汗る回折強度曲線を和の沶の 10 回測定し，ピーク位置の標準偏差を求めた結果でめる. Table I 中の $\bar{n}$ は測定面積 $4 \times 10 \mathrm{~mm}^{2}$, 摇動角度士 $6^{\circ}$ の場合に回折にあずかる結晶数を基準にそれぞれ の条件の之き回折にあずかる結晶数を比の形で表わし たものである. 回折にあずかる結晶数は装置の幾何学 的な条件によって近似的に求めることができる。すな わち, レートメータ法では, タイムコンスタントの值 によって，劣る時間幅の中に保存されている計数強度 が記録されていく、また，計数值の誤差は見かけ上 2 倍のタイムコンスタントの間に計数された計数值の測 定誤差と等しい，そこで，単位時間として 2 倍のタイ

Table I. Standard deviation of peak angle under various combinations of X-ray irradiated area and the oscillating angle.

\begin{tabular}{|c|c|c|c|c|}
\hline Measurement position & Fixed & \multicolumn{3}{|c|}{ Changed } \\
\hline Oscillatıng angle (deg) & \pm 6 & \pm 6 & \pm 1 & \pm 6 \\
\hline Oscillating area $\left(\mathrm{mm}^{2}\right)$ & $4 \times 10$ & $4 \times 10$ & $4 \times 10$ & $1.5 \times 2$ \\
\hline $\bar{n}$ & 1 & 1 & 0.22 & 0.06 \\
\hline Average peak angle & 156.37 & 156.37 & 156.36 & 056.35 \\
\hline $\begin{array}{l}\text { Standard deviation } \\
(\mathrm{deg})\end{array}$ & 0.015 & 0.016 & 0.076 & 0.017 \\
\hline
\end{tabular}

$\bar{n}$ : Relative ratio of the number of the grains contributing to the diffraction

ムコンスタント $2 t \sec$ をとると, 検出器が $2 t \sec$ 中 に試料を見达去角度範囲 $\Delta 2 \theta$ は次のよ5に示される。

$$
\Delta 2 \theta=2 \bar{\alpha}+2 t \cdot v
$$

ここで, $v$ は検出器走査速度であり, $\bar{\alpha}$ は有効に検 出されるX線の受光ソーラスリットに対する傾き角度 である。

いま，ソーラスリットの開さ角度を $\alpha$ とすると，士 $\alpha の$ 方向からのX線が通過するが，通過するX線の割 合は角度成分ごとに異なる．Fig. 1(a) に示すように， 受光ソーラスリットに平行な方向からのX線は $100 \%$ 検出器に入るが，ソーラスリットに対して傾いた方向 からのX線は一部がスリットでカットされる。このた め, 検出されるX線の強度は，Fig. 1(b) の上5に変 化し，ソーラスリットから $\alpha / 2$ 以上傾いた方向から のX線は庍とんど強度を与えない。そこで，有効に検 出されるX線の傾さ角度として，検出X線強度の $75 \%$ 以上を与をる範囲をとると $\bar{\alpha}=\alpha / 2$ となる。

(a)

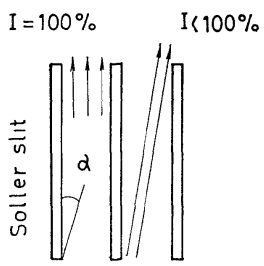

(Component perpendicular to the forl of the soller slit)

Fig. 1. Intensity of $\mathrm{X}$-rays passing through the receiving soller slit.

一方, 受光ソーラスリットの䇴に平行な方向では, Fig. 2(a) に示すように土及の方向からのX線が検出さ れる.この場合にも, 検出されるX線強度は Fig. 2(b) に示すように変化するため, 検出 $\mathrm{X}$ 線強度の $75 \%$ 以上 を与えるX線の傾き角度をるるすると

$$
\bar{\beta}=\left(D_{1}+D_{2}-\sqrt{D_{1} \cdot D_{2}}\right) / 2 l
$$

ここで， $D_{1}$ 特よび $D_{2}$ はそれぞれ応力測定方向に 直角な方向での検出器空の幅和よびX線照射幅, $l$ は 試料と検出器空の間の距離である.

試料の結晶方位に優位性がない場合，単位時間中に 検出強度に寄与する結晶数 $n$ は次のよ5に示される。

$$
n=K \cdot \frac{(\Delta 2 \theta \cdot 2 \bar{\beta} \cdot N)}{4 \pi}
$$

ここで，Kは常数，また，NはX線照射面積中の結 晶数であり, 結晶粒径 (結晶の一辺) を $R, \mathrm{X}$ 線照射 面積をSとすると, 次のように示される。

$$
N \simeq \frac{S}{R^{2}}
$$


(a)

(b)

Window of detector

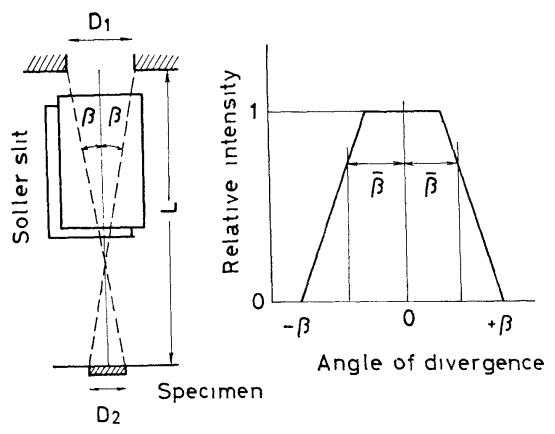

Irradiated area

(Component parallel to the forlof the soller slit)

F1g. 2. Intensity of $\mathrm{X}$-rays passing through the receiving soller slit.

$N$ はX線の浸入深さが 1 結晶粒以下である場合には, 測定体積中の結晶数となる.

ここで，士 $\Delta \psi$ の摇動を行なった場合には(1)式は(3) 式のようになる。

$$
n=K \cdot \frac{\{(\Delta 2 \theta+2 \Delta \psi) \cdot 2 \bar{\beta} \cdot S\}}{4 \pi \cdot R^{2}}
$$

ここで，2 $24 \psi$ は摇動角度範囲である。

Table I 飞执いてX線照射面積 $4 \times 10 \mathrm{~mm}^{2}$, 摇動角 度 $\pm 6^{\circ}$ の測定では, 測定位置を变光ても回折ピーク 位置のばらつき（標準偏差）には差がみられない。し かし, 摇動角度を \pm 10 飞すると, 回折ピークの標準 偏差は約 5 倍の大きさになる。この場合，回折年ず かる結晶数の比 $\bar{n}$ は $\pm 6^{\circ}$ 摇動の場合を 1 とすると約 0.2 になっている.X線照射面積 $1.5 \times 2 \mathrm{~mm}^{2}$, 摇動

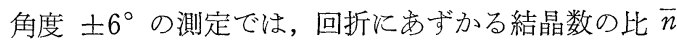
以最小である炕るかかわらず, 回折ピークの標準偏差 注员が最大の場合とほとえど同じ值を示している。し たがって，回折ピーク位置のばらつきを少なくするに は，単に回折沈すずかる結晶数を增すよりも，装置の 幾何学的な影響をとりの艺くことが重要と考觉られる。

このような観点から摇動角度の最低基準を考光てみ る.入射X線を摇動すると, X線の入射角度の変化飞 とるなって, 同一結晶の同一格子面が順次回折条件を 満足するようになる。回折強度曲線を三角形近似とし て扱うと，摇動角度範囲が半価幅以上の場合には，摇 動角範囲から半価幅を差し引いた角度範囲内で回折に 西ずかる結晶はそれぞれ完全な回折強度分布を示すよ

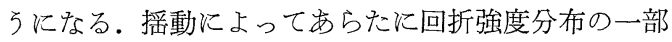
の強度を与兄る結晶るでてくるが, 摇動角度範囲が半 洒幅の 2 倍になると, 個々の結晶のうち, 強度分布の $80 \%$ 以上を示す結晶の数は(3)式より求めた回折飞あず かる結晶のうち約70\%になる。したがって，摇動を行
なわない場合に, 回折強度曲線に異常がみられる試料 では, 結晶の大きさに関係なく回折強度曲線の半価幅 の 2 倍以上を摇動角度範囲とすることが望しいと考党 られる。

\section{$2 \cdot 2$ ピーク強度を考慮した場合}

回折強度曲線の半価幅を基準傜動角度を決定して も，測定位置を変えたり，X線入射角度を変えると， 観測される回折ピーク強度が不規則に变化することも 多い。これは回折㐫ずかる結晶数が測定位置やX線 入射角度ごとに一定していないためと思われる。平均 化をさらによくするためには，回折ピーク強度を考慮 して摇動角度を決定する必要がある。Fig. 3 は摇動を 必要としない微小結晶粒のばね鋼に和汀る回折強度曲 線である。試料に結晶方位の優位性がなく，平均化す るのに充分な結晶数がある場合には, 回折ピーク強度

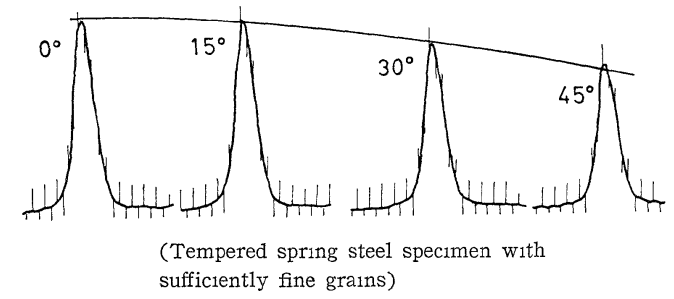

Fig. 3. Change of the peak intensity with the variation of incident angle $\psi_{0}$.

はX線入射角度に対して連続的に変化している。この よ5に正常な回折ピーク強度の変化を示すに充分な結 晶数を得るための摇動角度を考えてみる。(1)式で示さ れる $n$ を摇動を必要としない最小限の結晶数とすると, (1)，(2)，(3)式から摇動が必要な試料では次の条件を満 足すればよい。

$$
K \cdot \frac{(\Delta 2 \theta \cdot 2 \bar{\beta} \cdot S)}{4 \pi R^{2}}=K \cdot \frac{\left\{(\Delta 2 \theta+2 \Delta \psi) \cdot 2 \overline{\beta^{\prime}} \cdot S^{\prime}\right\}}{4 \pi R^{\prime 2}}
$$

ここで， $R ， S ， 2 \bar{\beta}$ はそれぞれ摇動を必要としない 場合の結晶粒径，X線照射面積拉よびX線の傾き角度

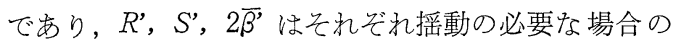
結晶粒径，X線照射面積特よびX線の傾き角度である。 (4)式より摇動角度範囲 $2 \Delta \psi$ は次のよ5に書き代えら れる。

$$
2 \Delta \psi=\Delta 2 \theta\left\{\left(\frac{R^{\prime}}{R}\right)^{2} \cdot\left(\frac{S}{S^{\prime}}\right) \cdot\left(\frac{2 \bar{\beta}}{2 \overline{\beta^{\prime}}}\right)-1\right\}
$$

X線照射面積が $4 \times 10 \mathrm{~mm}^{2}$ の場合，結晶粒径が 10 $\mu$ 以下では摇動を行なわなくても正常な回折ピーク強 度をるつ回折強度曲線が得られる。そこで，この条件 を基準に結晶粒径と摇動角度の関係を(5)式より求め Fig. 4 に示す.

Fig. 5 は顕微鏡観察 で平均結晶粒径 が $30 \mu, 50 \mu$ 


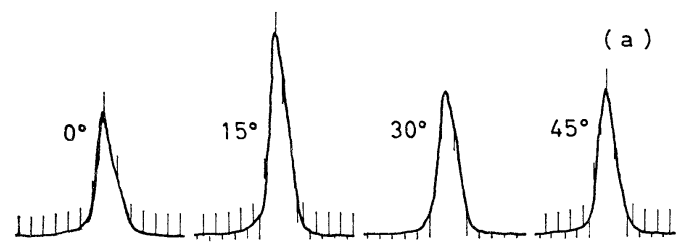

(b)
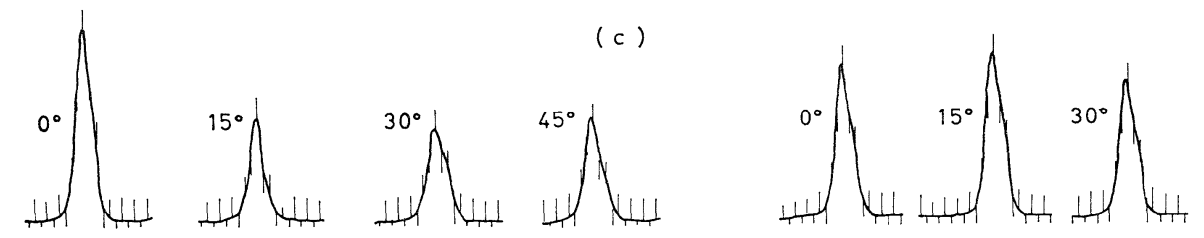

(d)

(e )

( $f$ )
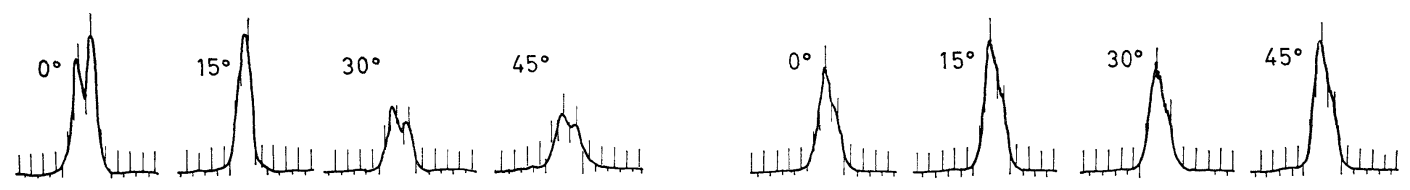

\begin{tabular}{lc|c|c|c|c|c|cc}
\hline \multicolumn{1}{c|}{ Condition } & & (a) & (b) & (c) & (d) & (e) & (f) \\
\hline Oscillating angel & $(\mathrm{deg})$ & 0 & \pm 6 & 0 & \pm 6 & 0 & \pm 11 \\
Grain size & $(\mu)$ & 30 & 30 & 50 & 50 & 100 & 100 \\
X-ray irradiated area & $\left(\mathrm{mm}^{2}\right)$ & $4 \times 6$ & $4 \times 6$ & $4 \times 10$ & $4 \times 10$ & $4 \times 10$ & $4 \times 10$ \\
\hline
\end{tabular}

Fig. 5. Change of diffraction line profile with incident angle $\psi_{0}$ in various oscillating conditions.

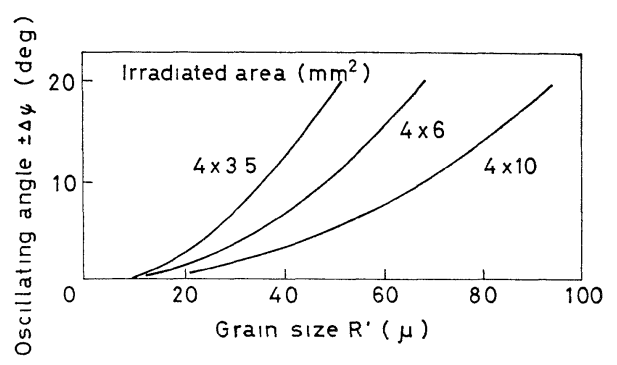

Fig. 4. Relation between grain size of specimen and the oscillating angle required to insure nomal diffraction line profile.

特よび $100 \mu$ の $\mathrm{Fe}$ 材の回折強度曲線である。いず れの試料も摇動を行なわない場合には, 回折ピーク強 度和よび回折強度曲線の形飞異常が見られるが，30

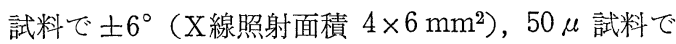
$\pm 6^{\circ}$ (X線照射面積 $4 \times 10 \mathrm{~mm}^{2}$ ) の摇動を行な5 ほぼ正常となる。また，100 試料では $\pm 11^{\circ}$ (X線 照射面積 $\left.4 \times 10 \mathrm{~mm}^{2}\right)$ の摇動でも回折ピーク強度が 異常である。これらの実験結果は前述の解析結果とよ く対応している。

以上述べたように, 摇動には装置の幾何学的な影響 によって生ずる回折ピーク位置のばらつきをとりのぞ く効果之, 回折㐫ずかる結晶数を增し, 回折強度曲
線のピーク強度を正常化する効果とがある。摇動角度 は測定目的に応じこれらの効果を考慮して決定されな ければならない。

\section{3 摇動条件と回折強度曲線}

摇動角度を大きくすると, 回折強度曲線上飞周期的 ならねりが目だつよらになる。このう䄈りは, 摇動角 度範囲に括壮る回折強度に差があるために生じ, X線 入射角度 $\psi_{0}$ の值が大きい注ど顕著である. 摇動速度 を速くするか，タイムコンスタントを大きくするとこ のう秝りを小さくすることが可能である。摇動速度は 回折図形上でタイムコンスタントと同じ効果を示し摇 動速度が大きくなると相対的にタイムコンスタントは 小さく, また検出器走査速度を速くすることも可能で ある、しかし, 摇動部分の重量が軽くないので摇動速 度を速くすることは不適当である。したがって，タイ ムコンスタントを大きくすることが望をしい，

Fig. 6 は $45^{\circ}$ 入射に特祆る回折強度曲線の一例であ る、試料は摇動を必要としない微小結晶粒のば㸚鋼を 用いた。.タイムコンスタントが小さく, 検出器走查速 度の大きい条件(b)では，回折強度曲線は大きくうねり， 回折ピーク位置の決定も難かしい。しかし,タイムコ ンスタントを大をとり，それ沉見合う遅い検出器走 


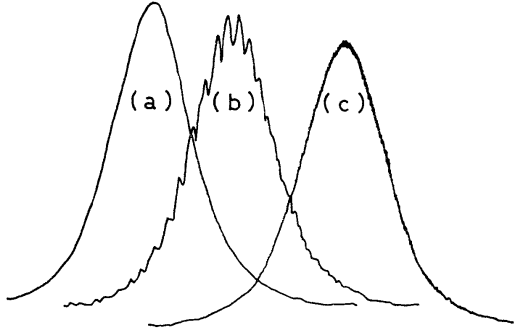

\begin{tabular}{lr|c|c|c}
\hline \multicolumn{1}{c|}{ Condition } & & (a) & (b) & (c) \\
\hline Oscillating angle & $(\mathrm{deg})$ & 0 & \pm 15 & \pm 15 \\
Oscillating speed & $(\mathrm{deg} / \mathrm{sec})$ & - & 2.8 & 2.8 \\
Scanning speed of detector $(\mathrm{deg} / \mathrm{min})$ & 2 & 2 & $1 / 4$ \\
Time constant & $(\mathrm{sec})$ & 8 & 8 & 64 \\
\hline
\end{tabular}

Fig. 6. Change of diffraction line profile with measuring condition.

査速度をとった条件(c)では, 回折強度曲線は摇動を行 なわない場合(a)に近く，う称りの注とえどない状態に なる。ただし，回折ピーク強度は若干低くなってくる。 この回折ピーク強度の減少は摇動角度と応力値の大小 に関連して変化する性質のものである。

Fig. 7 は回折ピーク位置に検出器を固定し，らねり の顕著な $45^{\circ}$ 入射で摇動を行なった場合に, 回折ピー ク位置でのうねりの振幅のピーク強度に対する比を士 $1 \%$ 以下に拉さえるタイムコンスタントの值を実験的 に求めた結果である。この結果から $\pm 10^{\circ}$ 以内の摇動 角度に対しては, 通常の測定でよく用いるタイムコン スタントの值 $8 \mathrm{sec} \sim 16 \mathrm{sec}$ を用いても，回折ピーク 位置の決定に不都合のないことがわかった。

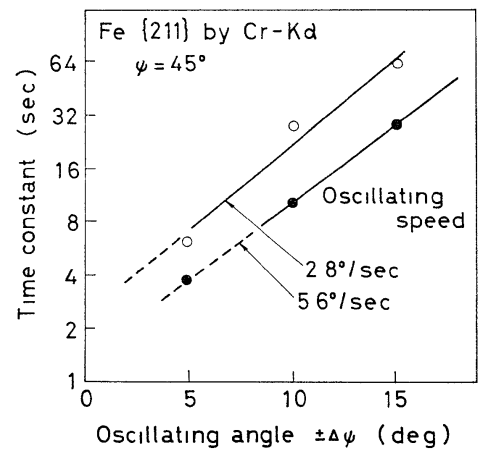

Fig. 7. Relation between time constant and oscillating angle, which is required to suppress periodic change in diffraction line profile.

\section{4 摇動と $X$ 線応力値}

一般にひずタ $\varepsilon_{\varphi \cdot \psi}$ は次のように示される。

$$
\varepsilon_{\varphi \cdot \psi}=\frac{1+\nu}{E} \cdot \sigma_{x} \cdot \sin ^{2} \psi-\frac{\nu}{E}\left(\sigma_{1}+\sigma_{2}\right)
$$

ここで, $E, \nu$ は弾性常数, $\sigma_{x}$ は測定方向の応力, $\sigma_{1}, \sigma_{2}$ は測定表面の主応力， $\varphi$ は $\sigma_{x}$ と $\sigma_{1}$ のなす角で 出る.X線入射角度を $\psi_{0}$ とし， $\eta=90^{\circ}-\theta_{\mathrm{Bragg}}$ とす ると $\psi_{0}$ を中心 $\pm \Delta \psi$ の摇動を行なった場合の測定

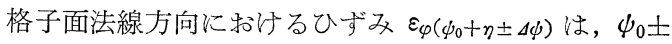
$\Delta \psi$ の角度範囲の単なる平均ではなく, 摇動角度範囲 飞和汗る回折強度の重みつき平均として求められる。 さきに述べたように, 回折強度はX線入射角度の值が 大きくなるにしたがって連続的に隇少する．Fe\{211\} を $\mathrm{Cr}-\mathrm{K} \alpha て ゙$ 測定した場合には， $\psi_{0}=0^{\circ}$ の回折ピーク 強度を $I_{0}, \psi_{0}=45^{\circ}$ の回折ピーク強度を $I_{45}$ とすると, $I_{0} / I_{45}$ は約 1.4 亿なるが，これは主として試料でのX 線の吸収がX線入射角度によって変化すること因っ ている.X線入射角度 $\psi_{0}$ に打忷る回折ピーク強度 $I_{\psi_{0}}$ は, $I_{\psi_{0}} \propto \cos \left(\psi_{0}+2 \eta\right) / \cos \left(\psi_{0}+\eta\right)$ として示される. 各入射角度 $\psi_{0}$ に和汀る $I_{\phi_{0}}$ を基準に土 $\Delta \psi$ 摇動を行 なったときのピーク強度 $I_{\psi_{0} \pm \Delta \psi}$ との比 $I_{\psi_{0} \pm \Delta \psi} / I_{\psi_{0}}$ で重みつき平均すると，ひずみ $\varepsilon_{\varphi} \cdot\left(\phi_{0}+\eta \pm \Delta \phi\right)$ は次の ように示すことができる.

$$
\begin{aligned}
\varepsilon_{\varphi} \cdot\left(\phi_{0}+\eta \pm \Delta \psi\right)= & \frac{1}{2 \Delta \psi} \int_{\phi_{0}-\Delta \psi}^{\phi_{0}+\Delta \psi}\left\{\frac{1+\nu}{E} \sigma_{x} \cdot \sin ^{2}(x+\eta)\right. \\
& \left.-\frac{\nu}{E}\left(\sigma_{1}+\sigma_{2}\right)\right\} \frac{\cos (x+2 \eta)}{\cos (x+\eta)} . \\
& \frac{\cos \left(\psi_{0}+\eta\right)}{\cos \left(\psi_{0}+2 \eta\right)} d x
\end{aligned}
$$

(7)式を展開すると次のようになる。

$$
\begin{aligned}
\varepsilon_{\varphi} \cdot\left(\psi_{0}+\eta \pm \Delta \psi\right)= & \frac{\sigma_{x}(1+\nu)}{2 E \Delta \psi} \cdot \frac{\cos \eta \cdot \cos \left(\psi_{0}+\eta\right)}{\cos \left(\psi_{0}+2 \eta\right)}[\Delta \psi \\
& +\frac{1}{2}\left\{\sin \left(\psi_{0}-\Delta \psi+\eta\right) \cdot \cos \left(\psi_{0}-\Delta \psi+\eta\right)\right. \\
& \left.-\sin \left(\psi_{0}+\Delta \psi+\eta\right) \cdot \cos \left(\psi_{0}+\Delta \psi+\eta\right)\right\} \\
& -\sin \eta\left\{\sin ^{2}\left(\psi_{0}-\Delta \psi+\eta\right)\right. \\
& -\sin ^{2}\left(\psi_{0}+\Delta \psi+\eta\right) \\
& \left.\left.+2 \log \frac{\left|\cos \left(\psi_{0}-\Delta \psi+\eta\right)\right|}{\left|\cos \left(\psi_{0}+\Delta \psi+\eta\right)\right|}\right\}\right] \\
& -\frac{\nu}{E}\left(\sigma_{1}+\sigma_{2}\right) \cdot \frac{\cos \left(\psi_{0}+\eta\right)}{\cos \left(\psi_{0}+2 \eta\right)}\{\cos \eta \\
& \left.-\frac{\sin \eta}{2 \Delta \psi} \cdot \log \frac{\left|\cos \left(\psi_{0}-\Delta \psi+\eta\right)\right|}{\left|\cos \left(\psi_{0}+\Delta \psi+\eta\right)\right|}\right\}(8)
\end{aligned}
$$

ここで(8)式を次のように書き表わすと

$$
\varepsilon_{\varphi} \cdot\left(\phi_{0}+\eta \pm \Delta \psi\right)=\frac{1+\nu}{2 E} \cdot \frac{\sigma_{x}}{\Delta \psi} \cdot F_{\psi}-\frac{\nu}{E}\left(\sigma_{1}+\sigma_{2}\right) \cdot G_{\psi}
$$

となり，2つのX線入射角度 $\psi_{1} ， \psi_{2}$ に和けるひずみ はそれぞれ(9)式，(10)式で表わされる。

$$
\begin{aligned}
\varepsilon_{\phi_{1}} & =\frac{1+\nu}{2 E} \cdot \frac{\sigma_{x}}{\Delta \psi} F_{\phi_{1}}-\frac{\nu}{E}\left(\sigma_{1}+\sigma_{2}\right) G_{\phi_{1}} \\
\varepsilon_{\psi_{2}} & =\frac{1+\nu}{2 E} \cdot \frac{\sigma_{x}}{\Delta \psi} F_{\psi_{2}}-\frac{\nu}{E}\left(\sigma_{1}+\sigma_{2}\right) G_{\psi_{2}}
\end{aligned}
$$

ひずみを $\operatorname{cosec} \theta$ で表わし，(9)，(10)式より応力 $\sigma_{x}$ を 求めると 


$$
\begin{aligned}
\sigma_{x}= & \frac{2 E \cdot \Delta \psi}{1+\nu} \cdot \frac{1}{F_{\phi_{1}} \cdot G_{\phi_{2}}-F_{\psi_{2}} \cdot G_{\phi_{1}}} \cdot\left(G_{\psi_{1}}-G_{\psi_{2}}\right. \\
& \left.+\frac{G_{\phi_{2}} \cdot \operatorname{cosec} \theta_{1}-G_{\phi_{1}} \cdot \operatorname{cosec} \theta_{2}}{\operatorname{cosec} \theta_{0}}\right)
\end{aligned}
$$

ここに, $\operatorname{cosec} \theta_{0}$ は無広力状熊での值であり, $\operatorname{cosec}$ $\theta_{1}, \operatorname{cosec} \theta_{2}$ はそれれぞれ $\psi_{1}, \psi_{2}$ に拉ける值である。

(11)式は摇動時の $\operatorname{cosec} \theta$ が $\sin ^{2} \psi$ に対して直線関 係にないこと示している。そこで，このような摇動 の影響を実験的に調べるたるに，負荷中の応力を測定 した。測定に用いた試料は SCM-5（焼入れ，㾕もど し材，半洒幅2. $6^{\circ}$ ) であり，測定格子面は $\{211\}$ で岁 る. 公称応力が 0 の場合, $71.3 \mathrm{~kg} / \mathrm{mm}^{2}$ の場合につ

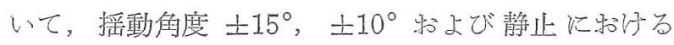
$\operatorname{cosec} \theta-\sin ^{2} \psi$ の関係定求的た。

Fig. 8 以摇動角度 土15の場合㸝よび静止の場合の $\operatorname{cosec} \theta-\sin ^{2} \psi$ 線図を示す。 $\pm 15^{\circ}$ 之大きな摇動角度 を選んでも，外応力が0の場合には，静止と摇動で

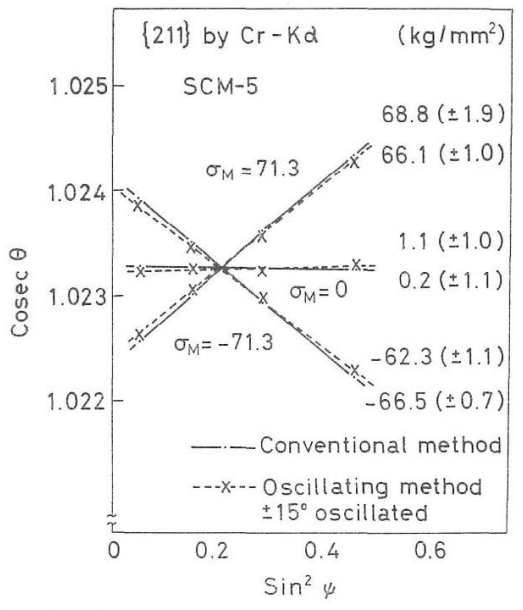

Fig. 8. $\operatorname{Cosec} \theta-\operatorname{Sin}^{2} \psi$ diagrams obtained from conventional method and the oscillating method.

$\operatorname{cosec} \theta$ の值に差が認められない。外応力を+71.3 $\mathrm{kg} / \mathrm{mm}^{2}$ あるいは $-71.3 \mathrm{~kg} / \mathrm{mm}^{2}$ 加えた場合には若 干の差を示した．引張応力の場合， $\phi$ が $0^{\circ}$ に近い側 で摇動時に $\operatorname{cosec} \theta$ の值が大きくなり， $\psi$ が $45^{\circ}$ に近 い側では小さくなる。逆に压縮応力の場合， $\psi$ が 近い側で摇動時に $\operatorname{cosec} \theta$ の值が小さくなり， に近い側では大きくなる。摇動角度が 士10゚の場合に は，静止と摇動で差が認められなかった。摇動時の $\operatorname{cosec} \theta$ は厳密には $\sin ^{2} \psi$ に刘して直線関係はないが， 実鈳的にほ上い直線関係がみられる。 $\operatorname{cosec} \theta-\sin ^{2} \psi$ 線 図孝用いて応力值を求わてみると, 公称応力に效する $\mathrm{X}$ 線的応力ほ機械的弾性常数亡X線的弾性常数の相違 によって若干少ない值を示した。また，士15摇動時 の応力ほ，静止の場合之比べて 4\%〜 6\%低くなるが， 摇動角度がさらに小さくてよい場合, 㐫るいは応力が
小さい場合には，摇動による測定值の誤差として，士 $2 \mathrm{~kg} / \mathrm{mm}^{2}$ 程度觉达呈ことにより $\operatorname{cosec} \theta-\sin ^{2} \psi$ 線 図党用いることが実用上有利と考完られる。

\section{5 応用例}

入射 X線摇動法は粗大結晶粒試料で，しか子， X線 照射面積が大きくとれない場合の応力測定に有效と考 えられる、そこで, 結晶粒径が約 $40 \mu の$ SPC-1 材 をスポット溶接し，ナゲット部近傍の曲げ負荷中の表 面応力を測定した。Fig.9はX線測定位置に和ける顕

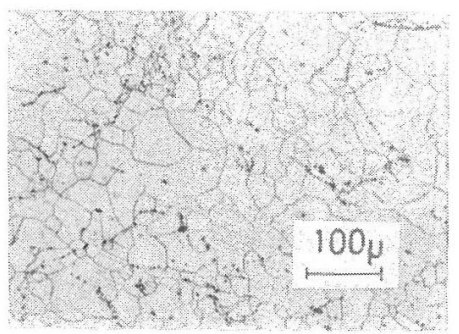

Fig. 9. Microstructure of the specimen (SPC-1).

微鏡写真である。局部的な応力測定を必要としたため， X線照射面積は応力測定方向に $1.2 \mathrm{~mm}$ ，旮れに直角 な方向に $2.2 \mathrm{~mm}$ とした。摇動角度 $\pm 6^{\circ}$, ソーラス リット開き触 $0.35^{\circ}$, 検出器走査速度 $1^{\circ} / \mathrm{min}$, 夕 イムコンスタント $16 \mathrm{sec}$ の各条件を用い， Cr $-\mathrm{K} \alpha$ に よる Fe $\{211\}$ の測定である。摇動㑲度は回折ピーク 強度委で正常化することはできないが，回折ピー多位 置のばらつきを充分にとりのぞくぎけの大きさ等選ん だ。

测定結果をFig. 10 飞示す。 $\operatorname{cosec} \theta-\sin ^{2} \psi$ 線图を用 い7 点のX線入射角度に看ける $\operatorname{cosec} \theta$ を最小自乗法 で整理し，応力值を算出した，X線による測定応力は $\pm 1 \mathrm{~kg} / \mathrm{mm}^{2} \sim \pm 2 \mathrm{~kg} / \mathrm{mm}^{2}$ の愦差匴囲をもb, 弾性 範国内では公称応力とよい直線関係を示した。この直

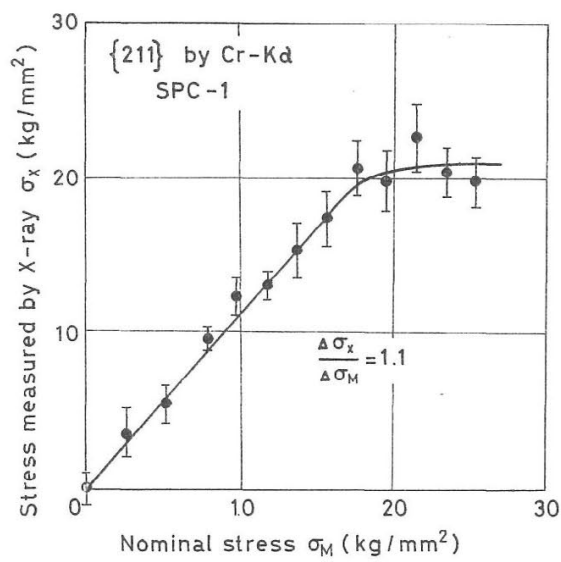

Fig. 10. Relation between stress measured by Xray and nominal stress in spot welded specimen (SPC-1). 
線の傾きは $\Delta \sigma_{x} / \Delta \sigma_{M}=1.1$ となって若干大きな值を示 しているが，これは測定位置が応力集中の影響のある ナゲット端近傍でめるためである。

\section{6 結 言}

入射X線摇動法を用いた応力測定に括沙る摇動角度 の決定基準を検討し, 回折強度曲線あるいは応力値へ の摇動の影響を調べた。 その結果, 次のようなことが 明らかとなった。

（1）摇動は装置の幾何学的な条件によって生ずる回 折強度曲線の形の異常を減少させ, 同時に, 回折にあ ずかる結晶数を増加させる。摇動角度範囲が半価幅の 2 倍以上飞なると，回折ピーク位置が容易に決定でき， 回折ピークのばらつきる小さい。

（2）摇動角度を大きくすると, 回折強度曲線上に周 期的なら䄈りが目だつょらになる。しかし，摇動角度 に応じた適当なタイムコンスタントを選べば，このう ねりをのぞくことが可能である。

(3) 摇動時の $\operatorname{cosec} \theta$ は $\sin ^{2} \psi$ に対して理論上直 線関係にないが，実用される摇動角度範囲に怙いては 直線からのはずれは微小であった。 $\pm 15^{\circ}$ の摇動時に
$\mathrm{Fe}\{211\}$ の応力值は, $\operatorname{cosec} \theta-\sin ^{2} \psi$ 線図で整理する と，若干小さい值を示すが，測定值の誤差として $\pm 2 \mathrm{~kg} / \mathrm{mm}^{2}$ 程度を見込むならば，実用的飞 $\sin ^{2} \psi$ 法 を用いることが有利である。

(4) 入射 X線摇動法を用いると, 平均結晶粒径が約 $40 \mu$ 之粗い結晶試料について, X線照射面積が $1.2 \times$ $2.2 \mathrm{~mm}^{2}$ の場合にも, $\pm 2 \mathrm{~kg} / \mathrm{mm}^{2}$ 程度の精度で応力 を測定することができた。

この他に, 摇動の影響として, 回折強度の变化や半 価幅の変化が応力值との関連で現われるが, これにつ いては別に検討が必要である.

(昭和45年 7 月17日 第 9 回X線材料強度汇関するシンポジウムにて講 演)

\section{参 考 文 献}

1）並川宏彦, 青山咸恒, 知久健夫, 材料, 18，1040(1969).

2) Cullity, B.D., (松村源太郎訳) “X線回折要論”, P. 211 (1968) アグネ

3）たと光ば，日本材料学会編，“X線応力測定法”， p. 87 （1966）養賢堂 